\title{
МЕТАЛЛИНКЛЮЗИРОВАННЫЕ ПОЛИМЕРЫ НА ОСНОВЕ ПОЛИВИНИЛПИРРОЛИДОНА
}

\section{Г.Д. Непочатый ${ }^{1,2}$, Е.А. Попова ${ }^{1,2}$, А.А. Артамонов' ${ }^{1}$ А.В. Еремин'}

\author{
${ }^{1}$ ИВС РАН, 199004, Россия, Санкт-Петербург, В. О. Большой пр., 31. \\ 2Факультет Химической и Биотехнологии, кафедра органической химии, СПбГТИ (ТУ), \\ 190013, Россия, Санкт-Петербург, Московский проспект, 26.
}

DOI: 10.19163/MedChemRussia2021-2021-518

E-mail:nepochatyy99@yandex.ru

Поливинилпирролидон (ПВП) является одним из ряда полимеров, наиболее часто применяемых в современной медицине и фармакологии. Практически нулевая токсичность, высокая способность к комплексообразованию - качества, благодаря которым ПВП нашел широкое применение в препаратах детоксикации организма или, например, носитель действующего вещества для пролонгирования действия лекарственных препаратов.

Одно из перспективных направлений использования комплексов поливинилпирролидона, его сополимерных систем, а также модифицированных полимерных систем с координированными ионами металлов $\mathrm{d}$ - и f-подгрупп является их применение в составе люминисцентных препаратов для окрашивания живых тканей, исследования физиологических процессов в клетке, в том числе и в режиме реального времени.

Нами предложена методология получения систем на основе ПВП и/ или его сополимеров, модифицированных привитыми ароматическими и гетеороароматическими фрагментов, и являющихся координационными сайтами для образования комплексов с металлами - медью(II), платиной(II/IV), европием(III), тербием и др. Данные системы, проявляя люминисцентную активность и являясь сложными системами «полимер-лиганд-металл» (polymerligand-metall systems (PLM-systems)), позволяют легко внести в живую ткань привитый к биосовместимому полимеру люминисцентный комплекс.

Одним из ключевых этапов предложенной методологии является реакция конденсации пирролидонового фрагмента с карбонильными ароматическими и гетероароматическими соединениями и их аналогами, которая позволяет привить к полимеру фрагменты, являющиеся подходящими лигандами для инклюзирования металла в модифицированную полимерную цепь и создания таким образом люминисцирующих материалов. 